\title{
Health Canada sidesteps commitment to new salt reduction strategy
}

Published at www.cmaj.ca on July 30

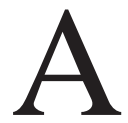
fter three years of "painfully slow and arduous" deliberations, Health Canada's Sodium Working Group has finally released recommendations for curbing the dangerously high levels of salt Canadians consume.

Now, a new round of the waiting game begins, as the federal government sidesteps a firm commitment to implement the group's advice at this time.

The Sodium Reduction Strategy for Canada calls on food manufacturers and restaurants to voluntarily cut sodium levels in their products, and on Health Canada to establish an independent monitoring and evaluation system to track industry compliance. The strategy also calls for prominent placement of sodium and calorie information for standard menu items at chain restaurants; an overhaul of food labelling to reduce the recommended "daily value" for sodium from $2400 \mathrm{mg}$ to $1500 \mathrm{mg}$; and an investment in education, awareness and research programs that further the goal of sodium reduction (www.hc -sc.gc.ca/fn-an/alt_formats/pdf/nutrition /sodium/strateg/index-eng.pdf).

The strategy aims to reduce the average Canadian's daily sodium intake to $2300 \mathrm{mg}$ per day by 2016 . According to the group, the average Canadian now consumes $3400 \mathrm{mg}$ of salt per day. Up to $85 \%$ of Canadian men, $83 \%$ of women, and $97 \%$ of children and teens consume levels of salt that are potentially dangerous to their health, said working group Vice Chair Dr. Mary L'Abbé, professor of nutritional sciences at the University of Toronto, during a July 29 press conference to announce the new strategy.

According to L'Abbé, the strategy "has the potential to save thousands of lives."

A reduction in the average Canadian's daily intake of sodium to

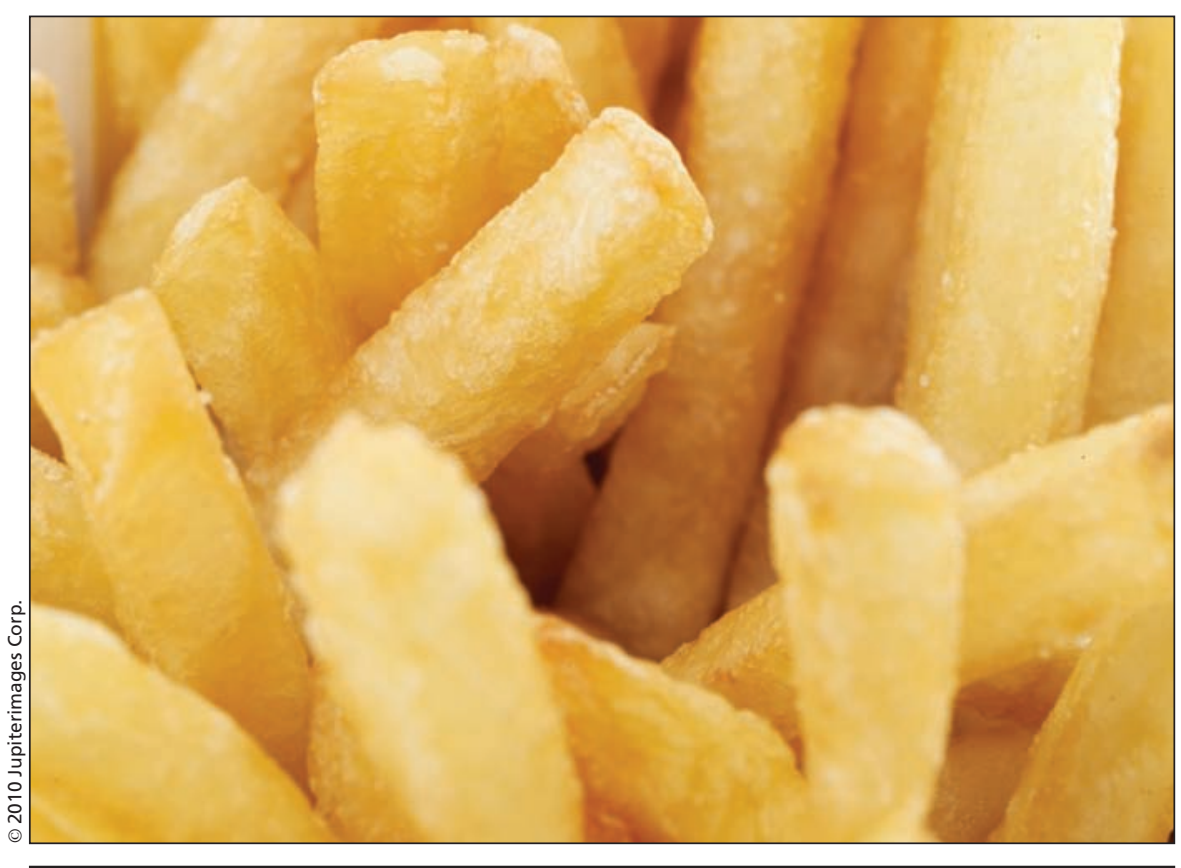

Health Canada's Sodium Working Group is calling on Canadians and industry to slash the levels of salt they use in preparing foods.

$1500 \mathrm{mg}$ would result in one million fewer patients with hypertension and 23500 fewer cardiac disease events per year, she said. According to 1993 estimates, such a reduction would result in $\$ 1.5$ billion in direct health care savings and $\$ 3$ billion in savings on indirect costs per year. That represents "significantly greater [savings] in 2010 dollars," L'Abbé added.

Federal Minister of Health Leona Aglukkaq issued a statement welcoming the recommendations, but both the minister and a commitment to implement the group's advice were absent at the time of the press conference to launch the strategy.

In her statement, Aglukkaq said that "Over the coming months, Health Canada will be working with its federal, provincial and territorial partners to assess the recommendations made by the working group and determine how they can best be addressed" (www.market wire.com/press-release/Government-of
-Canada-Welcomes-Sodium-Reduction -Report-1297556.htm).

This came as a disappointment to some members of the working group and health advocates.

"I don't think we should be tolerant of long periods of waiting and assessments. This report has been a long time coming and I don't think the recommendations are rocket science," said Dr. Norm Campbell, member of the working group and professor in the department of medicine at the University of Calgary in Alberta. "The government should have been expecting the recommendations and should be prepared to act on them."

Health Canada has given no timeline on when their deliberations will wrap up, but says they're already working to implement some of the group's recommendations.

"We're not just sitting back and studying the reports," said Dr. Hasan Hutchinson, chair of the working group 
and director general of the department's office of nutrition policy and promotion. "We're working on finishing off draft targets [for the food supply] for the end of the year. ... We've already started discussions with the [Canadian] Restaurant and Foodservices Association, working on targets that are specific to that sector as well."

Members of the working group and health advocates earlier this year called into question the government's commitment to public nutrition goals when a voluntary effort to reduce trans fats in the food supply failed to meet targets. In 2006, a task force representing both health experts and the food industry made a unanimous call for regulation of trans fats, but the government spent a year stalling before giving industry two years to make voluntary reductions. Despite industry failure to make those reductions, regulation is still nowhere on the horizon.
"Such a permissive approach to sodium reduction is reckless and could silently kill 15000 Canadians [annually]," said Bill Jeffery, national coordinator of the Center for Science in the Public Interest and member of both the sodium working group and trans fat task force. In an earlier interview with $C M A J$, Jeffery said he had "zero confidence" that government would follow through on the sodium working group's recommendations (www.cmaj.ca/cgi /doi/10.1503/cmaj.109-3284).

Meanwhile, the cost of retooling product lines, the loss of product shelf life, the loss of customers because of changes in product taste and a lack of alternatives to perform the preservative functions of salt will all act as barriers to voluntary change.

"Reducing sodium levels in processed food products and food service foods will be challenging in large part because of the complex role sodium plays in these foods," says Phyllis Tanaka, member of the working group and vice president of scientific and regulatory affairs for Food and Consumer Products of Canada. "[Salt] imparts flavour, acts a preservative and as an antimicrobial agent, and gives structure and texture to some foods."

While the strategy recommends "stronger measures" should be considered by government if the voluntary approach to sodium reduction fails, Canada's dependence on trade with the United States means any regulation of sodium will likely have to wait until similar efforts are possible south of the border. The US Department of Agriculture recently issued new guidelines restricting salt, along with sugar and saturated fat. - Lauren Vogel, CMAJ

DOI:10.1503/cmaj.109-3326 